\title{
Accuracy of Teleseismic Event Locations in the Middle East and North Africa
}

\author{
J. J. Sweeney
}

December 4, 1996

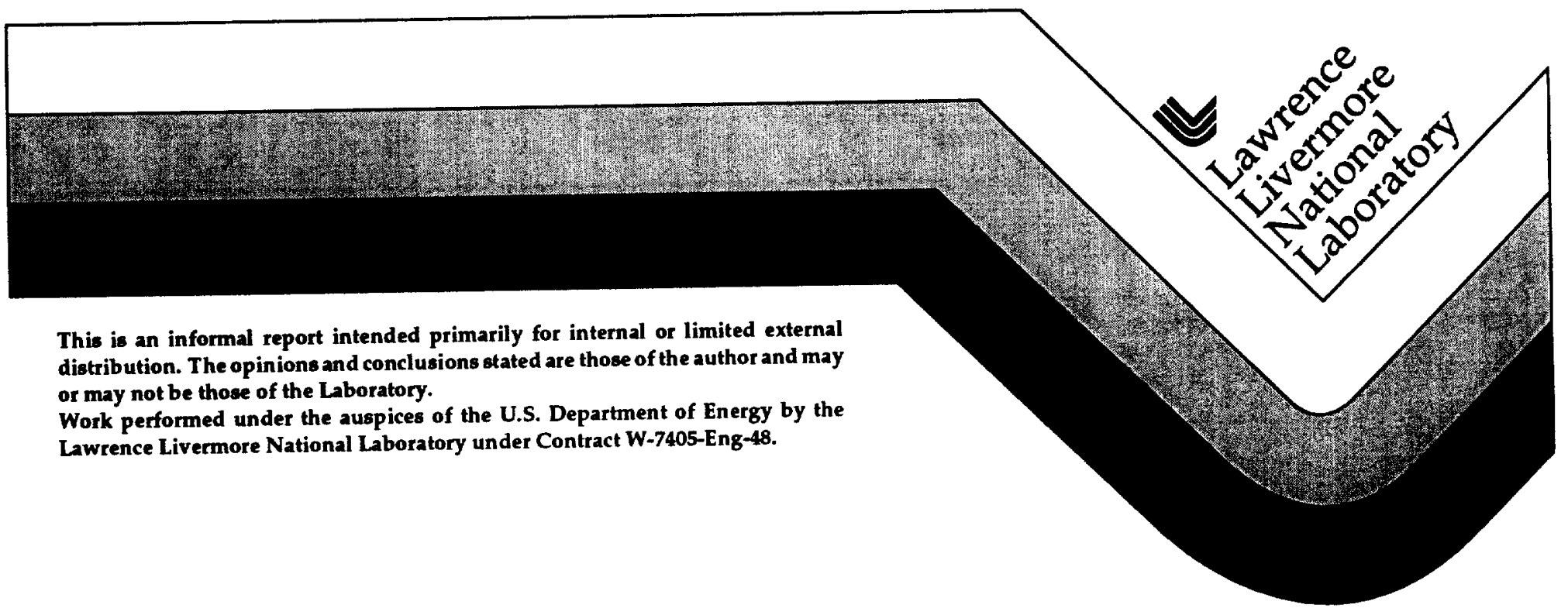




\section{DISCLAMMER}

This document was prepared as an sccount of work sponsored by an agency of the United States Covernment. Nelther the United States Covernment nor the Univerdty of California nor any of their

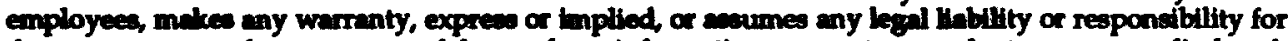
the accurncy, completeness, or usefulnes of any information, apparaten, product, or process disclosed, or represents that it we would not thiringe pitvalely owned righta. Reference herein to any spedfic commercial product, process, or service by trade neme, trademark, manuficturer, or otherwise, does not necesearily conetiute or imply it endoreenent, recommendation, or frvoring by the United States Government or the University of Callfornia. The vlews and opinion of athors expreesed herein do not necesearliy etate or reflect those of the United States Government or the University of California, and shall not be used for advertbing or product endarienent purposea.

This repart has been reproduced directly from the ben available copy.

\section{Avallable to DOE and DOE contractors from the Office of Sedentific and Technical Information P.O. Box 62, Onk Ridge, TN 37831}

Prices available from (615) 5\%6-8401, FTS 6268401

Avalisble to the public from the National Techrical information Service

U.S. Depertinent of Commerce 5285 Port Royal Rd., Springfield, VA 22161 


\title{
Accuracy of Teleseismic Event Locations in the Middle East and North Africa
}

\author{
Jerry J. Sweeney \\ Lawrence Livermore National Laboratory
}

\begin{abstract}
Seismic characterization at the regional level requires accurate determination of phases and travel times for many combinations of stations and events. An important consideration in the process is the accuracy of event locations. The LLNL Comprehensive Test Ban Treaty Research Program is currently working on data from the Middle East and North Africa, where seismic station coverage is relatively sparse and "ground truth" seismic source information is practically nonexistent. In this report I use aftershock studies as a source of local ground truth. I evaluate teleseismic location accuracy by comparing hypocenters determined by local networks with those determined teleseismically [e.g. the International Seismological Center (ISC) and the National Earthquake Information Center (NEIC)]. Epicentral locations, origin times, and depth determinations of events from three aftershocks studies (Algeria, Armenia, and Iran) and one local network study (Iran) are compared with ISC and NEIC locations for the same events. The key parameter for the ISC locations is the number of observations used in the location determination. For more than 40-50 observations (or stations), corresponding to an ISC $\mathrm{M}_{\mathrm{b}}$ of 4.4-4.5, ISC locations differ by less than $10-15 \mathrm{~km}$ from local network locations. With fewer than 40-50 observations, the agreement rapidly diminishes and ISC locations can differ from local determinations by as much as $80 \mathrm{~km}$ or more. Events in Iran show a distinct bias of ISC location errors toward the northeast; events in Armenia and Algeria show no directional bias. This study shows that only events with ISC $\mathrm{M}_{b}>4.4-4.5$ or NEIS $\mathrm{M}_{b}>$ 4.7-4.8 should be used for compiling travel time information from teleseismic bulletins in the Middle East/North Africa region when locations from the NEIC and ISC bulletins are used.
\end{abstract}

\section{Introduction}

The Comprehensive Test Ban Treaty Research Program at Lawrence Livermore National Laboratory (LLNL) is carrying out research to support US worldwide seismic monitoring efforts. Methods developed and data acquired under these efforts will eventually be used by the National Data Center (NDC), which will conduct monitoring for the Comprehensive Test Ban Treaty (CTBT). Current activities at LLNL are focused on the characterization of seismic propagation and evaluation of discriminant measures in the Middle East and North Africa (MENA) region (roughly the area encompassing the countries of Morocco, Algeria, Libya, Egypt, the Saudi Arabian peninsula, the Levant, Turkey, Iran, Iraq, and Syria). The goal of the project is to maximize the ability to locate events and to perform discrimination analysis (determine if the event is an earthquake, chemical explosion, or nuclear explosion) using regionally-located seismic arrays. The work is focused on MENA but not limited exclusively to it; some data may extend into outlying regions.

A key component of seismic characterization is the measurement of the travel times of regional seismic phases $\left(P_{n}, P_{g}, S_{n}, L_{g}\right)$ from events located at a range of distance and azimuth relative to the receiver station or array. The travel time data is then compared to global travel time models [such as IASP91 --Kennett and Engdahl (1991)] to make regional corrections for local variations due to geologic structure. In order to obtain accurate travel time residuals one must be certain that the events used in the calibration are well located (location errors $<10-20 \mathrm{~km}$ ). Thus "ground truth", i.e. accurate local information about event locations, is extremely important for 
regional seismic characterization. Controlled explosion sources provide ideal ground truth because their location and origin time can be precisely determined. Lacking such events and data from local catalogs, the next best ground truth available comes from aftershock studies.

A relatively common procedure in earthquake hazard studies is the practice of monitoring aftershocks of large damaging earthquakes. In such studies, local arrays of seismic instruments are set up around the epicenter of the earthquake to monitor and locate aftershocks which characterize the shape of the fault plane and the nature of slip. These studies are important for assessing future damage potential of the fault, measuring the moment and tectonic release of the earthquake, and in defining the seismotectonics of the region. If the local array is properly configured, hypocenters of local events of very low magnitude can be determined with errors as low as $1 \mathrm{~km}$ or less. These well-located events from the local array provide excellent ground truth for that region. In addition, inversion of local travel times of the aftershocks allows determination of an accurate velocity model of the crust in the vicinity of the events.

For this study I have researched published literature for reports of aftershock studies, or studies involving relocations of earthquakes based on local networks, in the Middle East and North Africa region. To date I have found four such studies from Iran, Algeria, and Armenia with aftershocks also reported in the International Seismic Center (ISC) event bulletin. The rest of this report consists of an analysis of the data from these studies, comparison with ISC and National Earthquake Information Center (NEIC) locations, and a discussion of the results.

\section{Events in Iran}

Berberian (1979b) compared the accuracy of teleseismic epicenters with the macroscopic (determined from surface ground breakage or damage assessments) epicenters of large magnitude events in Iran as a function of time as more instruments were added to the worldwide network of seismic stations. His figure 2 showed that the mean error of ISS-ISC locations compared to macroseismic epicenters was as high as $100 \mathrm{~km}$ prior to 1930 , decreasing to about $15 \mathrm{~km}$ by 1979 . The error of $15 \mathrm{~km}$ represents his assessment of the mean error in teleseismic locations of events of $M_{b} 6.0$ and higher with an instrumental system similar to that of the present ISC network.

Additional studies (Asudeh, 1983; Berberian, 1979a; Berberian, 1984) also point out that location errors for earthquakes in Iran can be quite large.

A local study in the Kermanshah region at the northwestern end of the Zagros Main Thrust by Niazi et al. (1978) showed that there are often large errors in event locations in Iran, especially in the Zagros mountain range and for smaller events. In a more comprehensive study, Jackson (1980) used a plot of the number of ISC station P-phase determinations for an event location versus the ISC focal depth to demonstrate that events with depths greater than $70-80 \mathrm{~km}$ were found only when the number of stations was less than 100 . This suggests that smaller events may have large errors in depth determination. In the paper, Jackson also states that "...nobody has identified a pP phase below $60-70 \mathrm{~km}$ in the Zagros"; thus reliable data shows that seismicity occurs mainly above the Moho in the Zagros mountain belt and that claims for the occurrence of subduction beneath Zagros are suspect. What is true for the Zagros region doesn't apply to the Makran region; Jackson (1980) noted that a relatively large earthquake located at a depth of $110 \mathrm{~km}$ in the Makran region (where subduction of oceanic crust is occurring) is probably accurately located.

In a study by Asudeh (1983), seven earthquakes were re-located using P-wave arrival data from local stations and the assumption of $30 \mathrm{~km}$ focal depth with a crustal model revised from the Jeffreys-Bullen model used by the ISC (Adams, 1992). Table II of Asudeh's paper lists the origin 
time and location of the relocated events and compares these with the location and origin times determined by the ISC. Also included in Asudeh's table is the ISC focal depth, a local magnitude determination, the ISC magnitude, the number of local stations used, the number of stations used in the ISC determination, and the horizontal difference in location. I used the locations from Table II of Asudeh (1983) to recalculate the difference in location using the LLNL Seismic Analysis Code (SAC). These calculated distances are slightly different from those of Asudeh. Two of the events in Asudeh's Table II had differences in location of more than $200 \mathrm{~km}$ compared to the local network and I did not use these. The remaining five events that I compared to the ISC locations are listed in Table 1. Also listed in Table 1 are locations determined by the NEIC from the Preliminary Determination of Epicenters (PDE) catalog. ISC - local network location differences vary from $7.2 \mathrm{~km}$ to $107.6 \mathrm{~km}$, with the largest differences in location being for events with the smallest number of ISC stations (and the lowest magnitude). Note that two of the events well located by the ISC, with 108 and 194 stations, have focal depth determinations of $60 \mathrm{~km}$ and $53 \mathrm{~km}$, respectively. Origin times can differ by up to 5 seconds for the more poorly-located events. These well-located events are somewhat deep for earthquakes in Zagros, according to Jackson and Fitch (1981). The NEIC events seem to show better agreement with Asudeh's locations, especially in depth and considering that fewer stations were used. Figure 1 shows a plot, similar to Fig. 3 of Asudeh (1983), of the difference in location between the Asudeh relocations and the ISC locations. In Fig. 1 (and similar figures to follow) I have scaled symbol size of the relocated events (white circles) by the local network ISC $\mathrm{M}_{\mathrm{b}}$ to demonstrate that smaller events have much larger location errors than the larger events. More will be said about this in the Discussion section below. Figure 1 shows that events of $M_{b} 4.0$ or smaller can have location errors of as much as 100 $\mathrm{km}$. This small set of relocations suggests that there is a spacial bias to the ISC locations, which puts them to the northeast of their true location. The azimuthal gap for the ISC events is listed in the last column on the right of Table 1. (The NEIC PDE bulletin does not list the reporting stations, and hence there is no back azimuth information.) For Zagros, the azimuthal gaps indicate poor station coverage in the region southeast to southwest of the events. Most of the reporting stations are in Europe, to the west-northwest and northern Asia, to the northeast.

In another study in Iran, a temporary array of seismic instruments was deployed by Cambridge University in the epicentral region of the 1978 Tabas-e-Golshan $\mathrm{M}_{\mathrm{s}} 7.4$ earthquake, in which over 20,000 people were killed. Details of the deployment and an assessment of the local tectonics are given by Berberian (1984). Many of the aftershocks from this earthquake were recorded by the Iranian Long Period Array (ILPA) which was operational near Tehran in 19781979. A collection of events from the ILPA dataset has been assembled by Multimax, Inc. (see http://www.multimax.com/ gtdb on the internet). Berberian's thesis, Berberian (1981), contains a listing of 329 well located events (his Table V.4). Out of this listing, I found six events that are also listed in the ISC catalog. Of these six, four are also contained in the Multimax, Inc. ILPA listing. Table 2 compares ISC and Cambridge network locations, origin times, and depth determinations for these events. None of these events are listed in the NEIC PDE catalog. ISC magnitudes $\left(\mathrm{M}_{\mathrm{b}}\right)$ of the events vary from 4.2 (lower values were estimated from the network local magnitudes) to 4.9. Differences in location range from $9 \mathrm{~km}$ to $86.7 \mathrm{~km}$; differences in origin time range from $2.3 \mathrm{~s}$ to $10.9 \mathrm{~s}$. ISC depths are mostly indeterminate (listed as $33 \mathrm{~km}$ ) with the network depth determinations ranging from $8.3 \mathrm{~km}$ to $30 \mathrm{~km}$ with a cluster around $12 \mathrm{~km}$ depth. Figure 2, a plot with the same format as Fig. 1, shows that the ISC locations have a bias toward the NNE-NE relative to the network locations; this is similar to what was seen for the Asudeh relocations. The 
azimuthal gap for the Tabas events is similar to Zagros, with poor station coverage to the south. Again, the smaller events (in this case events with $\mathrm{M}_{\mathrm{b}}<4.5$ ) show the largest ISC location differences. The aftershock listing of Berberian (1981) provides a particularly valuable ground truth dataset because many of the aftershocks not listed in the ISC bulletin were also recorded by ILPA and the waveform data for these events are available for analysis.

\section{An aftershock study in Algeria}

After the October $1980 \mathrm{El}$ Asnam, Algeria $\mathrm{M}_{\mathrm{s}} 7.3$ earthquake, a portable network of 28 stations was used to monitor aftershocks for 5 weeks (Yielding et al., 1989). A total of 4517 aftershocks were located in the Yielding et al. study. For this study, I used the 91 events listed in Appendix 3 of Yielding et al. (1989), which is a subset for which fault plane solutions were obtained. All of the 91 events had depth determinations which were less than $10 \mathrm{~km}$, with mainly thrust and strike-slip mechanisms. Magnitudes (locally determined using HYPOINVERSE) of the 91 events ranged from 1.87 to 4.25 . A total of eight of these events had locations determined by the ISC and three events had locations determined by the NEIC. A comparison of the ISC, NEIC, and local network locations of the eight events is given in Table 3 and Fig. 3.

Note that some ISC magnitudes, when determined, show large departures from the local magnitudes. I have not included a comparison of origin times in Table 3 because Yielding et al. (1989) listed the network origin times only to the minute. Differences in location range from 87.2 $\mathrm{km}$ to $1.9 \mathrm{~km}$; both of these extremes occur for relatively small events. In this case some of the events well located by the ISC are also small events, but other small events can show great differences in location. The NEIC locations generally are comparable to the ISC locations, usually with fewer stations used by the NEIC. In this case, for Algeria (Fig. 3), there appears to be no azimuthal bias to the location differences as was seen in Iran. Poorest azumuthal station coverage appears to be toward the southeast, which is toward the African continent and Indian Ocean.

\section{An Aftershock Study in Armenia}

An aftershock study of the December 1988 Spitak, Armenia, $M_{s} 6.9$ earthquake was reported by Dorbath et al. (1992). As was the case with the El Asnam earthquake, this earthquake sequence consisted of shallow thrust fault events with depths less than $10 \mathrm{~km}$. During the study, a $100 \mathrm{Kg}$ explosion was used to calibrate upper crustal velocities. The aftershock study and the calibration data were used with a master event method to relocate the main shock and a series of aftershocks. Of the 76 relocated aftershocks listed in Table 4 of the Dorbath et al. paper, 13 were also listed in the ISC Bulletin and 11 in the NEIC PDE catalog. A comparison of the network, ISC, and NEIC locations and origin times is given in Table 4 and Fig. 4 below. The ISC magnitudes varied from $\mathrm{M}_{\mathrm{b}} 4.2$ to 4.8. Differences in origin time between the ISC and network determinations range from 0.6 to $14.5 \mathrm{~s}$, with epicentral differences ranging from 4.8 to $105.3 \mathrm{~km}$. In most cases, the NEIC locations are farther from the local network locations than are the ISC locations, although the origin times agree more closely. There are always fewer stations used in the NEIC determinations than for the ISC determinations. As Fig. 4 shows, there is no strong azimuthal bias to the location differences. In general, the largest events show the least difference in location, although one small event shows a small difference as well. 
Table 1: Comparison of regional network, ISC, and NEIC locations for earthquakes in the Zagres region (after Asudeh, 1983)

\begin{tabular}{|l|l|l|l|l|l|l|l|l|l|l|}
\hline Event ID & Source & $\begin{array}{c}\text { Origin } \\
\text { Time } \\
(\mathrm{h} \mathrm{m} \mathrm{s})\end{array}$ & Lat & Lon & $\begin{array}{c}\text { Depth } \\
(\mathrm{km})\end{array}$ & $\mathrm{M}_{\mathrm{b}}$ & $\begin{array}{c}\text { Origin } \\
\text { time } \\
\text { diff. (s) }\end{array}$ & $\begin{array}{c}\text { Epicen- } \\
\text { tral diff. } \\
(\mathbf{k m})\end{array}$ & $\begin{array}{c}\text { No. of } \\
\text { sta- } \\
\text { tions }\end{array}$ & $\begin{array}{c}\text { Max. Az. } \\
\text { gap } \\
\text { (range) }\end{array}$ \\
\hline \hline $760902 \mathrm{a}$ & network & 121729.6 & $32.1 \mathrm{~N}$ & $49.75 \mathrm{E}$ & 30 & 3.9 & & & & \\
\hline & ISC & 121735 & $32.2 \mathrm{~N}$ & $49.9 \mathrm{E}$ & - & -- & 5.4 & 18 & 4 & $139^{\circ}-312^{\circ}$ \\
\hline $760902 \mathrm{~b}$ & network & 221829.6 & $32.0 \mathrm{~N}$ & $49.69 \mathrm{E}$ & 30 & 3.7 & & & & \\
\hline & ISC & 221835 & $32.1 \mathrm{~N}$ & $50.3 \mathrm{E}$ & 33 & -- & 5.4 & 58.7 & 4 & $141^{\circ}-311^{\circ}$ \\
\hline 760905 & network & 164317.3 & $31.35 \mathrm{~N}$ & $49.95 \mathrm{E}$ & 30 & 4.8 & & & & \\
\hline & ISC & 164316.8 & $31.41 \mathrm{~N}$ & $49.98 \mathrm{E}$ & 53 & 5.1 & -0.5 & 7.2 & 194 & $128^{\circ}-180^{\circ}$ \\
\hline & NEIC & 164315.8 & $31.43 \mathrm{~N}$ & $49.97 \mathrm{E}$ & 44 & 5.1 & -1.5 & 9.2 & 95 & \\
\hline 760906 & network & 160445.7 & $31.07 \mathrm{~N}$ & $50.39 \mathrm{E}$ & 30 & 4.7 & & & & \\
\hline & ISC & 160447.3 & $31.07 \mathrm{~N}$ & $50.46 \mathrm{E}$ & 60 & 4.9 & 1.6 & 6.7 & 108 & $128^{\circ}-201^{\circ}$ \\
\hline & NEIC & 160445.1 & $31.13 \mathrm{~N}$ & $50.37 \mathrm{E}$ & 39 & 5.0 & -0.6 & 6.5 & 51 & \\
\hline 760910 & network & 115519 & $31.3 \mathrm{~N}$ & $49.93 \mathrm{E}$ & 30 & 4.3 & & & & \\
\hline & ISC & 115522 & $31.7 \mathrm{~N}$ & $51.0 \mathrm{E}$ & 129 & 3.7 & 3.0 & 107.6 & 11 & $4^{\circ}-147^{\circ}$ \\
\hline & NEIC & 115516.4 & $31.57 \mathrm{~N}$ & $49.78 \mathrm{E}$ & 33 & 4.0 & -2.6 & 25.5 & 8 & \\
\hline
\end{tabular}

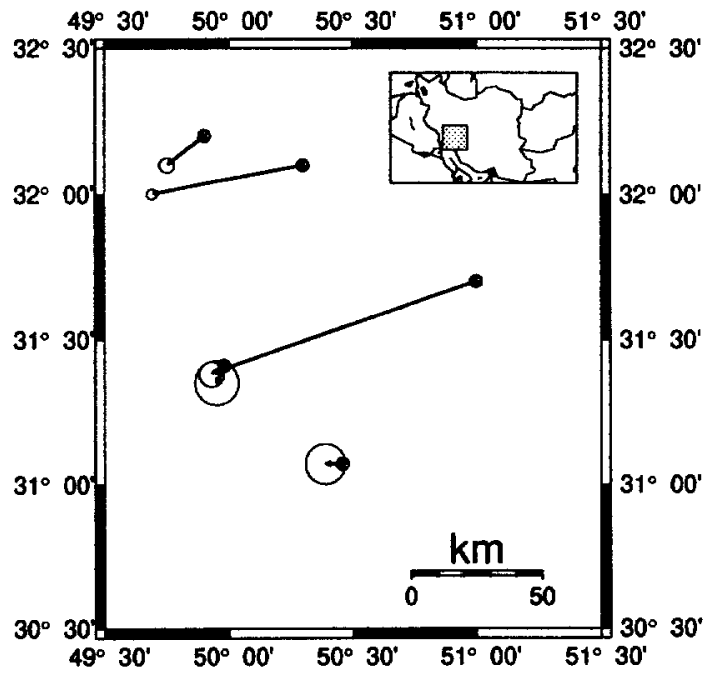

Figure 1. Relocation of earthquakes in the Zagros region of Iran (see inset), after Asudeh (1983). Shaded circles are ISC locations, white circles are relocations by Asudeh from regional network data and assuming a $30 \mathrm{~km}$ focal depth. White circle diameter is scaled by the square of the regional network magnitude (which ranges from $M_{b} 3.7$ to 4.9 ). 
Table 2: Comparison of local network and ISC locations for aftershocks of the Tabas-eGolshan, Iran, earthquake (after Berberian, 1981).

\begin{tabular}{|l|l|l|l|l|l|l|l|l|l|l|}
\hline $\begin{array}{c}\text { Event } \\
\text { ID }\end{array}$ & Source & $\begin{array}{c}\text { Origin } \\
\text { Time } \\
(\mathrm{h} \mathrm{m} \mathrm{s)}\end{array}$ & Lat & Lon & $\begin{array}{c}\text { Dept } \\
\mathbf{h} \\
(\mathrm{km})\end{array}$ & $\mathbf{M}_{\mathbf{b}}$ & $\begin{array}{c}\text { Origin } \\
\text { time } \\
\text { diff. (s) }\end{array}$ & $\begin{array}{c}\text { Epicen- } \\
\text { tral diff. } \\
(\mathrm{km})\end{array}$ & $\begin{array}{c}\text { No. of } \\
\text { sta- } \\
\text { tions }\end{array}$ & $\begin{array}{c}\text { Max. Az. } \\
\text { gap } \\
\text { (range) }\end{array}$ \\
\hline \hline 781001 & network & 104947.5 & $33.42 \mathrm{~N}$ & $57.25 \mathrm{E}$ & 12.6 & 3.1 & & & & \\
\hline & ISC & 104955 & $34.0 \mathrm{~N}$ & $57.4 \mathrm{E}$ & 33 & 4.3 & 7.5 & 65.5 & 10 & $124^{\circ}-225^{\circ}$ \\
\hline $781009 \mathrm{a}$ & network & 004243.5 & $33.21 \mathrm{~N}$ & $57.33 \mathrm{E}$ & 30.0 & 3.7 & & & & \\
\hline & ISC & 004253 & $33.4 \mathrm{~N}$ & $57.6 \mathrm{E}$ & 33 & 4.4 & 9.5 & 33.1 & 12 & $125^{\circ}-230^{\circ}$ \\
\hline $781009 \mathrm{~b}$ & network & 160437.0 & $33.34 \mathrm{~N}$ & $57.34 \mathrm{E}$ & 18.0 & 3.7 & & & & \\
\hline & ISC & 160443 & $33.44 \mathrm{~N}$ & $57.31 \mathrm{E}$ & 46 & 4.6 & 6.0 & 11.3 & 46 & $137^{\circ}-228^{\circ}$ \\
\hline 781012 & network & 150138.7 & $33.35 \mathrm{~N}$ & $57.34 \mathrm{E}$ & 11.3 & 4.0 & & & & \\
\hline & ISC & 150141 & $33.39 \mathrm{~N}$ & $57.43 \mathrm{E}$ & 18 & 4.9 & 2.3 & 9.0 & 77 & $133^{\circ}-230^{\circ}$ \\
\hline 781016 & network & 211656.9 & $33.39 \mathrm{~N}$ & $57.27 \mathrm{E}$ & 8.3 & 3.5 & & & & \\
\hline & ISC & 211705 & $33.8 \mathrm{~N}$ & $57.4 \mathrm{E}$ & 33 & - & 8.1 & 46.6 & 8 & $118^{\circ}-226^{\circ}$ \\
\hline 781019 & network & 143956.1 & $33.52 \mathrm{~N}$ & $57.11 \mathrm{E}$ & 11.9 & 3.1 & & & & \\
\hline & ISC & 144007 & $34.3 \mathrm{~N}$ & $57.2 \mathrm{E}$ & 33 & - & 10.9 & 86.7 & 5 & $95^{\circ}-222^{\circ}$ \\
\hline
\end{tabular}

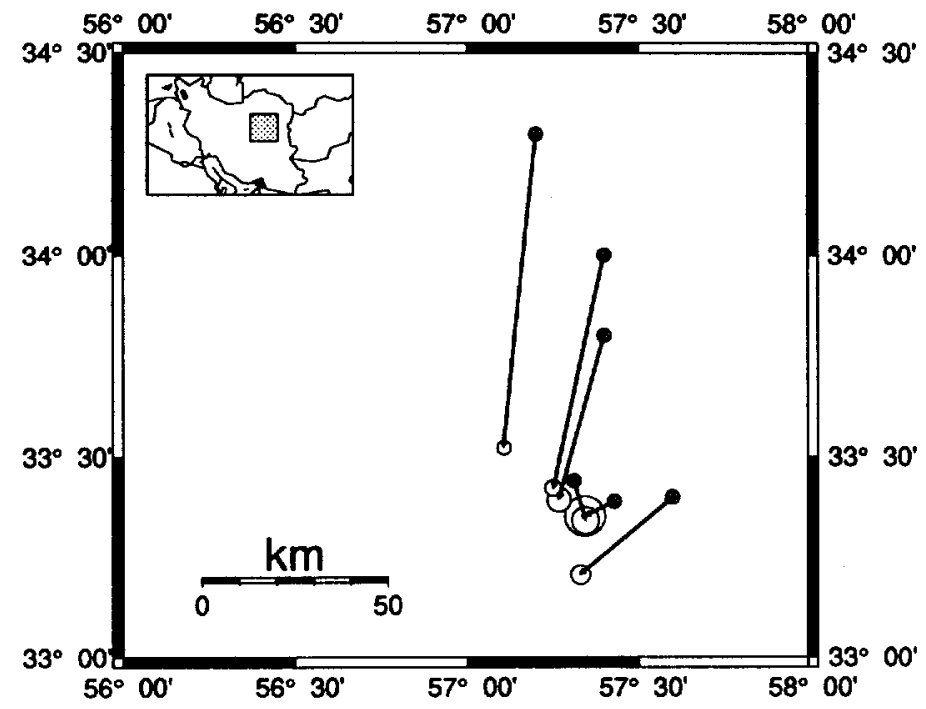

Figure 2. Comparison of locations of aftershocks of the Tabas-e-Golshan earthquake. Small shaded circles are ISC locations. White circles are locations determined from the local network (refer to Table 2) and scaled by ISC magnitude as in Fig. 1 ( $\mathrm{M}_{\mathrm{b}}$ range is 4.2-4.9 - two indeterminate ISC magnitudes were estimated by comparison with the local magnitudes). 
Table 3: Comparison of local network, ISC, and NEIC locations for aftershocks of the El Asnam, Algeria, earthquake (after Yielding et al., 1989).

\begin{tabular}{|c|c|c|c|c|c|c|c|c|c|c|}
\hline $\begin{array}{c}\text { Event } \\
\text { ID }\end{array}$ & Source & $\begin{array}{l}\text { Origin } \\
\text { Time } \\
(\mathrm{h} \mathrm{m} \mathrm{s)}\end{array}$ & Lat & Lon & $\begin{array}{c}\text { Dept } \\
\text { h } \\
(\mathrm{km})\end{array}$ & $\mathbf{M}_{\mathrm{b}}$ & $\begin{array}{l}\text { Origin } \\
\text { time } \\
\text { diff. (s) }\end{array}$ & $\begin{array}{c}\text { Epicen- } \\
\text { tral diff. } \\
(\mathrm{km})\end{array}$ & $\begin{array}{c}\text { No. of } \\
\text { sta- } \\
\text { tions }\end{array}$ & 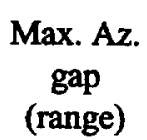 \\
\hline \multirow[t]{3}{*}{801029} & network & 013000 & $36.34 \mathrm{~N}$ & $1.72 \mathrm{E}$ & 5.49 & 4.15 & & & & \\
\hline & ISC & $\begin{array}{l}0130 \\
09.8\end{array}$ & $36.4 \mathrm{~N}$ & $1.77 \mathrm{E}$ & 10 & 4.2 & & 8.5 & 41 & $73^{\circ}-231^{\circ}$ \\
\hline & NEIC & 013011.2 & $36.41 \mathrm{~N}$ & $1.58 \mathrm{E}$ & 10 & 4.4 & & 14.9 & 10 & \\
\hline \multirow[t]{3}{*}{801030} & network & 002338 & $36.36 \mathrm{~N}$ & $1.69 \mathrm{E}$ & 4.56 & 3.74 & & & & \\
\hline & ISC & 002338.1 & $36.36 \mathrm{~N}$ & $1.65 \mathrm{E}$ & 1 & 5.3 & & 3.7 & 280 & $85^{\circ}-132^{\circ}$ \\
\hline & NEIC & 075418.2 & $36.11 \mathrm{~N}$ & $1.36 \mathrm{E}$ & 10 & 5.3 & & 4.8 & 143 & \\
\hline \multirow[t]{2}{*}{801108} & network & 075400 & $36.14 \mathrm{~N}$ & $1.40 \mathrm{E}$ & 5.47 & 4.08 & & & & \\
\hline & ISC & 075417.4 & $36.12 \mathrm{~N}$ & $1.38 \mathrm{E}$ & 4 & 5.4 & & 2.4 & 305 & $163^{\circ}-183^{\circ}$ \\
\hline \multirow[t]{2}{*}{801109} & network & 183000 & $36.46 \mathrm{~N}$ & $1.63 \mathrm{E}$ & 6.32 & 4.18 & & & & \\
\hline & ISC & 183043 & $36.3 \mathrm{~N}$ & $1.8 \mathrm{E}$ & 0 & - & & 23.2 & 5 & $356^{\circ}-232^{\circ}$ \\
\hline \multirow[t]{2}{*}{801111} & network & 012900 & $36.45 \mathrm{~N}$ & $1.63 \mathrm{E}$ & 6.33 & 3.74 & & & & \\
\hline & ISC & 012915 & $36.45 \mathrm{~N}$ & $1.71 \mathrm{E}$ & 0 & -- & & 7.3 & 10 & $27^{\circ}-231^{\circ}$ \\
\hline \multirow[t]{2}{*}{801115} & network & 001200 & $36.22 \mathrm{~N}$ & $1.67 \mathrm{E}$ & 6.48 & 3.56 & & & & \\
\hline & ISC & 001212.3 & $36.7 \mathrm{~N}$ & $0.9 \mathrm{E}$ & 0 & -- & & 87.2 & 6 & $2^{\circ}-225^{\circ}$ \\
\hline \multirow[t]{2}{*}{ 801110a } & network & 222800 & $36.32 \mathrm{~N}$ & $1.64 \mathrm{E}$ & 4.54 & 3.51 & & & & \\
\hline & ISC & 222844.7 & $36.13 \mathrm{~N}$ & $1.41 \mathrm{E}$ & - & -- & & 29.1 & 3 & $313^{\circ}-231^{\circ}$ \\
\hline \multirow[t]{2}{*}{$801110 b$} & network & 210800 & $36.12 \mathrm{~N}$ & $1.39 \mathrm{E}$ & 6.35 & 3.49 & & & & \\
\hline & ISC & 210849.5 & $36.13 \mathrm{~N}$ & $1.41 \mathrm{E}$ & - & - & & 1.9 & 4 & $313^{\circ}-231^{\circ}$ \\
\hline \multirow[t]{3}{*}{801108} & network & 020600 & $36.46 \mathrm{~N}$ & $1.62 \mathrm{E}$ & 4.46 & 3.83 & & & & \\
\hline & ISC & 020658.5 & $36.56 \mathrm{~N}$ & $1.59 \mathrm{E}$ & -- & - & & 11.8 & 178 & $94^{\circ}-143^{\circ}$ \\
\hline & NEIC & 020658.3 & $36.51 \mathrm{~N}$ & $1.59 \mathrm{E}$ & 10 & 4.6 & & 6.7 & 73 & \\
\hline
\end{tabular}




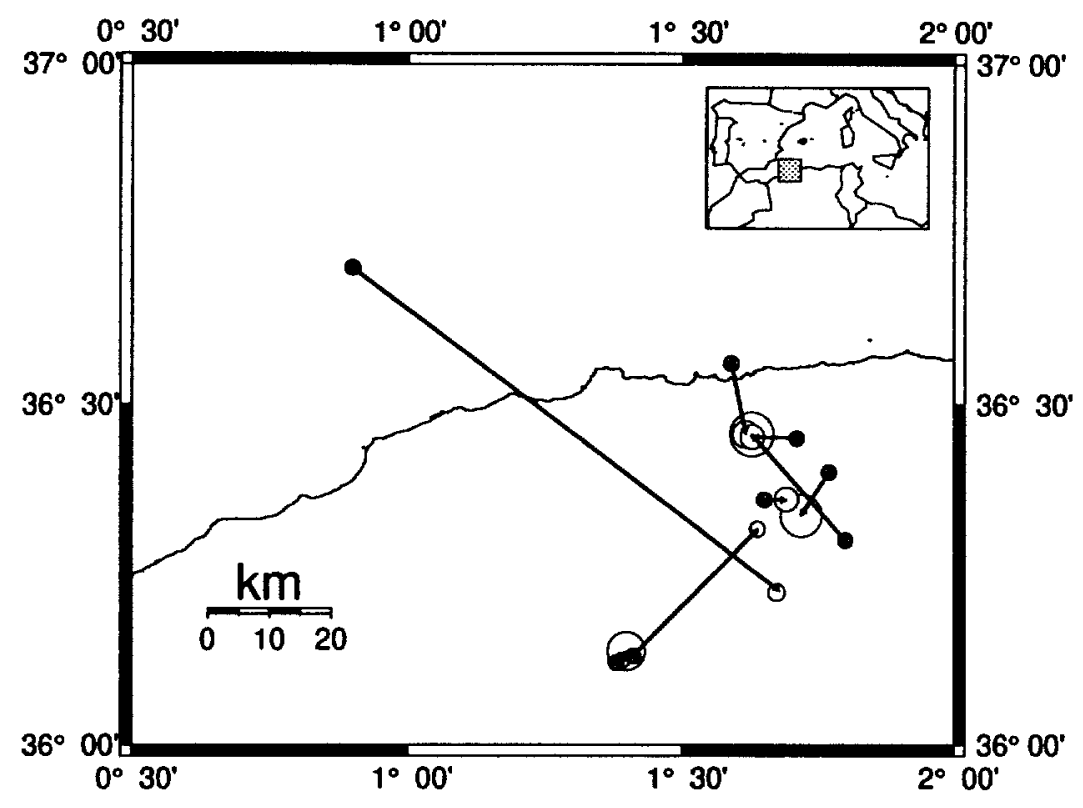

Figure 3. Comparison of locations of aftershocks of the El Asnam earthquake. Small shaded circles are ISC locations. White circles are locations determined from the local network (refer to Table 3) and scaled by network magnitude as in Fig. 1 ( $\mathrm{M}_{\mathrm{b}}$ range is 3.5-4.2).

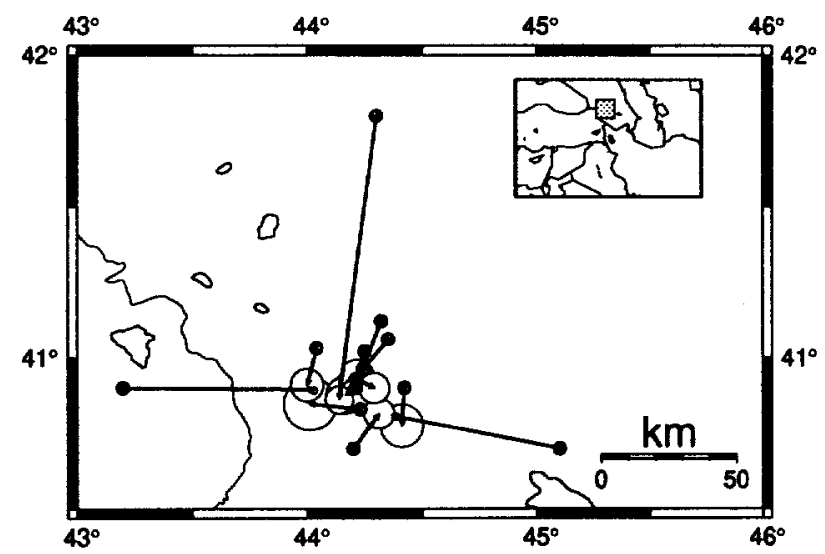

Figure 4. Comparison of locations of aftershocks of the Spitak earthquake. Small shaded circles are ISC locations. White circles are locations determined from the local network (refer to Table 4 on the next page) and scaled by network magnitude as in Fig. $1\left(M_{b}\right.$ range is 3.0-4.9). 
Table 4: Comparison of local network, ISC, and NEIC locations for aftershocks of the Spitak, Armenia earthquake (after Dorbath et al., 1992).

\begin{tabular}{|c|c|c|c|c|c|c|c|c|c|c|}
\hline $\begin{array}{c}\text { Event } \\
\text { ID }\end{array}$ & Source & $\begin{array}{c}\text { Origin } \\
\text { Time } \\
(\mathrm{h} \mathrm{m} \mathrm{s})\end{array}$ & Lat & Lon & $\begin{array}{c}\text { Dept } \\
\text { h } \\
(\mathrm{km})\end{array}$ & $\mathbf{M}_{\mathrm{b}}$ & $\begin{array}{l}\text { Origin } \\
\text { time } \\
\text { diff. (s) }\end{array}$ & $\begin{array}{c}\text { Epicen- } \\
\text { tral diff. } \\
(\mathbf{k m})\end{array}$ & $\begin{array}{c}\text { No. of } \\
\text { sta- } \\
\text { tions }\end{array}$ & $\begin{array}{c}\text { Max. Az. } \\
\text { gap } \\
\text { (range) }\end{array}$ \\
\hline \multirow[t]{3}{*}{$881207 a$} & network & 080626.4 & $40.85 \mathrm{~N}$ & $44.01 E$ & 4.89 & 4.9 & & & & \\
\hline & ISC & 080629 & $40.83 \mathrm{~N}$ & $44.23 \mathrm{E}$ & 16 & 4.7 & 2.6 & 18.6 & 48 & $162^{\circ}-275^{\circ}$ \\
\hline & NEIC & 080628.1 & $\begin{array}{l}40.903 \\
\mathrm{~N}\end{array}$ & $44.396 \mathrm{E}$ & 10 & 4.8 & 1.7 & 33.1 & 22 & \\
\hline \multirow[t]{3}{*}{$881207 \mathrm{~b}$} & network & 085703.5 & $40.89 \mathrm{~N}$ & $44.03 \mathrm{E}$ & 4.2 & 3.0 & & & & \\
\hline & ISC & 085706.3 & $40.90 \mathrm{~N}$ & $43.20 \mathrm{E}$ & 10 & 4.4 & 2.8 & 69.7 & 8 & $5^{\circ}-138^{\circ}$ \\
\hline & NEIC & 085706.1 & $\begin{array}{l}40.936 \\
\mathrm{~N}\end{array}$ & $43.209 \mathrm{E}$ & 10 & 4.6 & 2.6 & 69.1 & 7 & \\
\hline \multirow[t]{3}{*}{$881207 \mathrm{c}$} & network & 092837.5 & $40.8 \mathrm{IN}$ & $44.38 \mathrm{E}$ & 6.34 & 3.0 & & & & \\
\hline & ISC & 092852 & $40.70 \mathrm{~N}$ & $45.10 \mathrm{E}$ & 10 & 4.4 & 14.5 & 61.9 & 8 & $350^{\circ}-160^{\circ}$ \\
\hline & NEIC & 092851.3 & $40.69 \mathrm{~N}$ & $45.37 \mathrm{E}$ & 10 & 4.6 & 13.8 & 84.5 & 5 & \\
\hline \multirow[t]{2}{*}{$881207 d$} & network & 105650.4 & $40.88 \mathrm{~N}$ & $44.21 \mathrm{E}$ & 6.34 & 4.2 & & & & \\
\hline & ISC & 105651 & $40.96 \mathrm{~N}$ & $44.24 \mathrm{E}$ & 2 & 4.7 & 0.6 & 8.8 & 32 & $219^{\circ}-303^{\circ}$ \\
\hline \multirow[t]{2}{*}{$881207 \mathrm{e}$} & network & 141014.5 & $40.94 \mathrm{~N}$ & $44.22 \mathrm{E}$ & 66.34 & 4.3 & & & & \\
\hline & ISC & 141016.9 & $41.06 \mathrm{~N}$ & $44.35 \mathrm{E}$ & 10 & 4.3 & 2.4 & 17.4 & 50 & $192^{\circ}-270^{\circ}$ \\
\hline \multirow[t]{3}{*}{$881207 f$} & network & 180541.8 & $40.88 \mathrm{~N}$ & $44.16 \mathrm{E}$ & 4.2 & 4.4 & & & & \\
\hline & ISC & 180542 & $40.90 \mathrm{~N}$ & $44.21 \mathrm{E}$ & 2 & 4.4 & 0.2 & 4.8 & 49 & $219^{\circ}-295^{\circ}$ \\
\hline & NEIC & 180542.8 & $\begin{array}{l}40.952 \\
\mathrm{~N}\end{array}$ & $44.160 \mathrm{E}$ & 10 & 4.6 & 1.0 & 8.5 & 13 & \\
\hline \multirow[t]{3}{*}{$881207 \mathrm{~g}$} & network & 191751.5 & $40.86 \mathrm{~N}$ & $44.14 \mathrm{E}$ & 6.34 & 4.1 & & & & \\
\hline & ISC & 191758 & $41.80 \mathrm{~N}$ & $44.30 \mathrm{E}$ & 10 & 4.2 & 6.5 & 105.3 & 9 & $350^{\circ}-156^{\circ}$ \\
\hline & NEIC & 191756.6 & $\begin{array}{l}41.690 \\
\mathrm{~N}\end{array}$ & $44.750 \mathrm{E}$ & 10 & 4.4 & 5.1 & 105.5 & 5 & \\
\hline \multirow[t]{3}{*}{$881207 \mathrm{~h}$} & network & 200728.9 & $40.91 \mathrm{~N}$ & $44.22 \mathrm{E}$ & 6.34 & 4.4 & & & & \\
\hline & ISC & 200731 & $41.12 \mathrm{~N}$ & $44.32 \mathrm{E}$ & 7 & 4.4 & 2.1 & 24.5 & 49 & $219^{\circ}-269^{\circ}$ \\
\hline & NEIC & 200730.3 & $\begin{array}{l}41.208 \\
\mathrm{~N}\end{array}$ & 44.471E & 10 & 4.6 & 2.4 & 39.1 & 13 & \\
\hline \multirow[t]{3}{*}{$881208 a$} & network & 014938.2 & $40.91 \mathrm{~N}$ & $44.00 \mathrm{E}$ & 4.2 & 4.3 & & & & \\
\hline & ISC & 014940 & $41.03 \mathrm{~N}$ & $44.04 \mathrm{E}$ & 7 & 4.2 & 1.9 & 13.8 & 39 & $219^{\circ}-255^{\circ}$ \\
\hline & NEIC & 014941 & $\begin{array}{l}40.955 \\
\mathrm{~N}\end{array}$ & $43.401 \mathrm{E}$ & 10 & 4.3 & 2.8 & 50.6 & 10 & \\
\hline
\end{tabular}


Table 4: Comparison of local network, ISC, and NEIC locations for aftershocks of the Spitak, Armenia earthquake (after Dorbath et al., 1992).

\begin{tabular}{|l|l|l|l|l|l|l|l|l|l|l|}
\hline $\begin{array}{c}\text { Event } \\
\text { ID }\end{array}$ & Source & $\begin{array}{c}\text { Origin } \\
\text { Time } \\
(\mathrm{h} \mathrm{m} \mathrm{s})\end{array}$ & \multicolumn{1}{|c|}{ Lat } & Lon & $\begin{array}{c}\text { Dept } \\
\mathbf{h} \\
(\mathbf{k m})\end{array}$ & $\mathrm{M}_{\mathrm{b}}$ & $\begin{array}{c}\text { Origin } \\
\text { time } \\
\text { diff. (s) }\end{array}$ & $\begin{array}{c}\text { Epicen- } \\
\text { tral diff. } \\
(\mathrm{km})\end{array}$ & $\begin{array}{c}\text { No. of } \\
\text { sta- } \\
\text { tions }\end{array}$ & $\begin{array}{c}\text { Max. Az. } \\
\text { gap } \\
\text { (range) }\end{array}$ \\
\hline \hline $881208 \mathrm{~b}$ & network & 074600.4 & $40.78 \mathrm{~N}$ & $44.41 \mathrm{E}$ & 6.34 & 4.6 & & & & \\
\hline & ISC & 074603.3 & $40.90 \mathrm{~N}$ & $44.42 \mathrm{E}$ & 22 & 4.8 & 2.9 & 13.9 & 105 & $228^{\circ}-255^{\circ}$ \\
\hline & NEIC & 074601.4 & 40.874 & $44.336 \mathrm{E}$ & 10 & 4.6 & 1.0 & 12.6 & 37 & \\
\hline $881208 \mathrm{c}$ & network & 203205.8 & $40.89 \mathrm{~N}$ & $44.20 \mathrm{E}$ & 6.34 & 4.5 & & & & \\
\hline & ISC & 203206.4 & $41.02 \mathrm{~N}$ & $44.25 \mathrm{E}$ & 10 & 4.8 & 0.6 & 15.1 & 130 & $220^{\circ}-266^{\circ}$ \\
\hline & NEIC & 203206.4 & 41.147 & $44.206 \mathrm{E}$ & 10 & 4.8 & 0.6 & 28.5 & 53 & \\
\hline 881210 & network & 191357.8 & $40.82 \mathrm{~N}$ & $44.31 \mathrm{E}$ & 5.46 & 4.2 & & & & \\
\hline & ISC & 191358.6 & $40.70 \mathrm{~N}$ & $44.20 \mathrm{E}$ & 10 & 4.4 & 0.8 & 15.8 & 10 & $343^{\circ}-112^{\circ}$ \\
\hline & NEIC & 191359 & $40.76 \mathrm{~N}$ & $44.08 \mathrm{E}$ & 10 & 4.5 & 1.2 & 20.4 & 7 & \\
\hline 881212 & network & 153617.2 & $40.90 \mathrm{~N}$ & $44.29 \mathrm{E}$ & 5.46 & 4.2 & & & & \\
\hline & ISC & 153618.1 & $40.93 \mathrm{~N}$ & $44.21 \mathrm{E}$ & 10 & 4.5 & 0.9 & 7.5 & 35 & $219^{\circ}-295^{\circ}$ \\
\hline & NEIC & 153617.9 & $40.82 \mathrm{~N}$ & $44.26 \mathrm{E}$ & 10 & - & 0.7 & 9.2 & 10 & \\
\hline
\end{tabular}

\section{Discussion}

The epicentral difference between ISC, NEIC, and local network aftershock locations are compared in Fig. 5, where location data from Tables 1-4 are plotted as a function of the number of ISC or NEIC stations reporting for each event. (Usually, for smaller events where the only phase is the first $P$ arrival, the number of defining phases will equal the number of stations, so I use the terms "number of stations" and "number of phases" interchangeably.) Events with more than 150 stations reporting generally show differences of $10 \mathrm{~km}$ or less when compared with local networks, so I have only plotted the data up to 150 stations to better represent what happens when few stations are used in the ISC locations. Figure 5 shows that when less than 50 stations are used in the ISC locations the differences with local network location determinations can become quite large, especially when the number of stations reporting is less than 20 . Results are similar for the NEIC data, although they start to depart at 50-60 stations. The number of teleseismic stations reporting for a given event depends on the location of the event within the network and, consequently, shows quite a bit of variation with magnitude. Using the data for the three aftershock studies examined here, the ISC magnitude corresponding to 50 stations reporting is typically about $\mathrm{M}_{\mathrm{b}} 4.4$ - 4.5. This is closer to $\mathrm{M}_{\mathrm{b}} 4.7$ - 4.8 for NEIC locations. Thus we can assume from this study that events larger than about $\mathrm{M}_{\mathrm{b}} 4.4-4.5$ have ISC locations accurate to about $15 \mathrm{~km}$ or less. A somewhat larger magnitude is needed for similar accuracy for NEIC locations. 


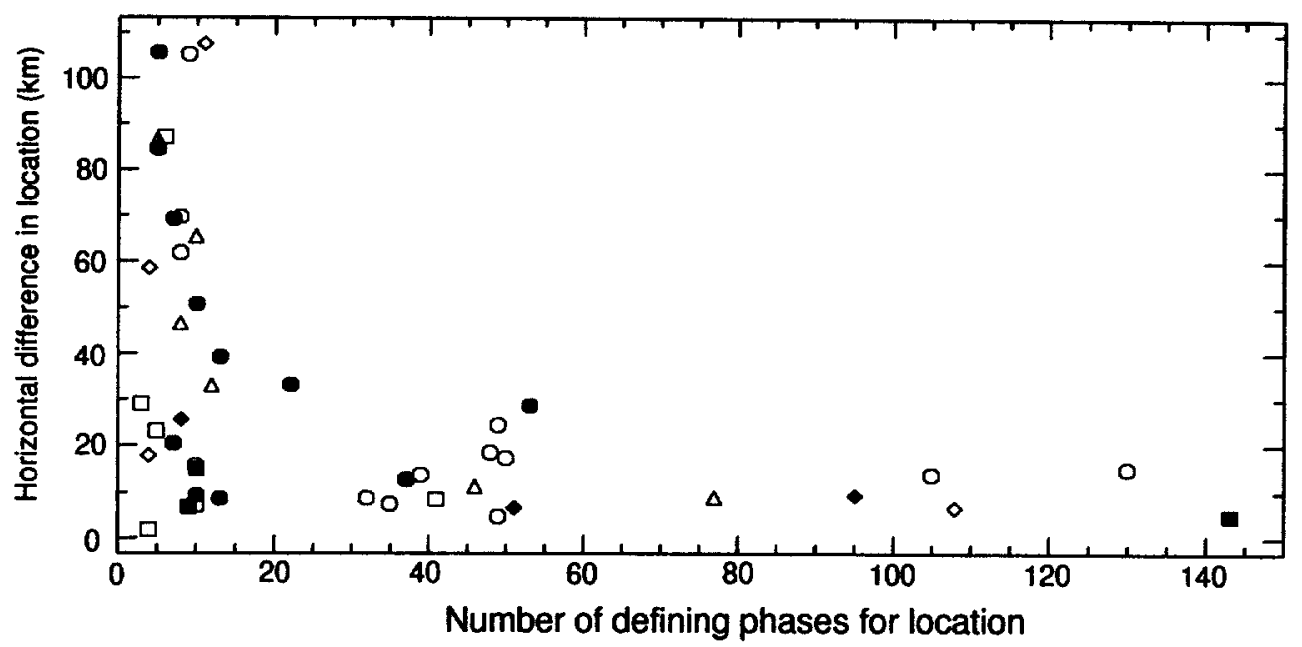

Figure 5. Location differences between ISC, NEIC, and the local networks as a function of the number of stations used in determining the event location. Open symbols are ISC determinations; solid symbols are NEIC determinations. Symbols are as follows: triangles - Tabas Iran, squares - El Asnam Algeria, circles - Spitak Armenia, diamonds - Zagros Iran.

The ISC depth determinations are much less reliable than the locations. For the Spitak earthquake (Table 4) the ISC depths showed shallow depths which were close to, but generally smaller or larger than the network determinations. In Armenia, the ISC depth determinations suggested shallow events, but the depth values were not reliable. In Iran, the ISC depth determinations were consistently much too deep, at least in the Zagros, and can not be considered reliable even for fairly large events. This probably indicates that the Jeffreys-Bullen velocity model is a poor fit to regional structure in Iran, but not as bad for northern Algeria. NEIC depth determinations seem to be slightly better than the ISC determinations.

Figure 6 shows the difference in depth between the local network and teleseismic determinations. NEIC determinations don't show a trend toward larger differences with fewer stations as the ISC data do. The biggest depth differences are for the Tabas aftershocks; as the number of stations reporting decreases, the teleseismic depth determination gets deeper. This agrees with the observations of Jackson (1980). Note that all of the aftershocks for these three aftershock sequences are shallow, being generally less than $15 \mathrm{~km}$; the teleseismic depths are often listed as zero (refer to the tables).

Differences in origin time as a function of the number of phases (stations) reporting are shown in Fig. 7. Differences are generally less than $2.5 \mathrm{~s}$ until the number of stations is less than 50 or 60 . NEIC determinations of origin time tend to be closer to those determined by the local networks than the ISC times are. In Fig. 8, the dependence of epicentral location difference on azimuthal gap is shown for the ISC determinations. The plot shows that fairly good locations (10$20 \mathrm{~km}$ ) can be obtained with azimuthal gaps up to $200^{\circ}$, but very poor locations can also be expected when the gap is greater than $50^{\circ}$. Figure 9 illustrates the trade-off between origin time and depth. Most of the Armenia and Tabas data show that the depth determination difference will be about $1 \mathrm{~km}$ for each $1 / 3$ second difference in origin time, as represented by the dotted lines in Fig. 9. This slope is similar to that determined for an Iran/Iraq earthquake analyzed by Billings et al. (1988). 


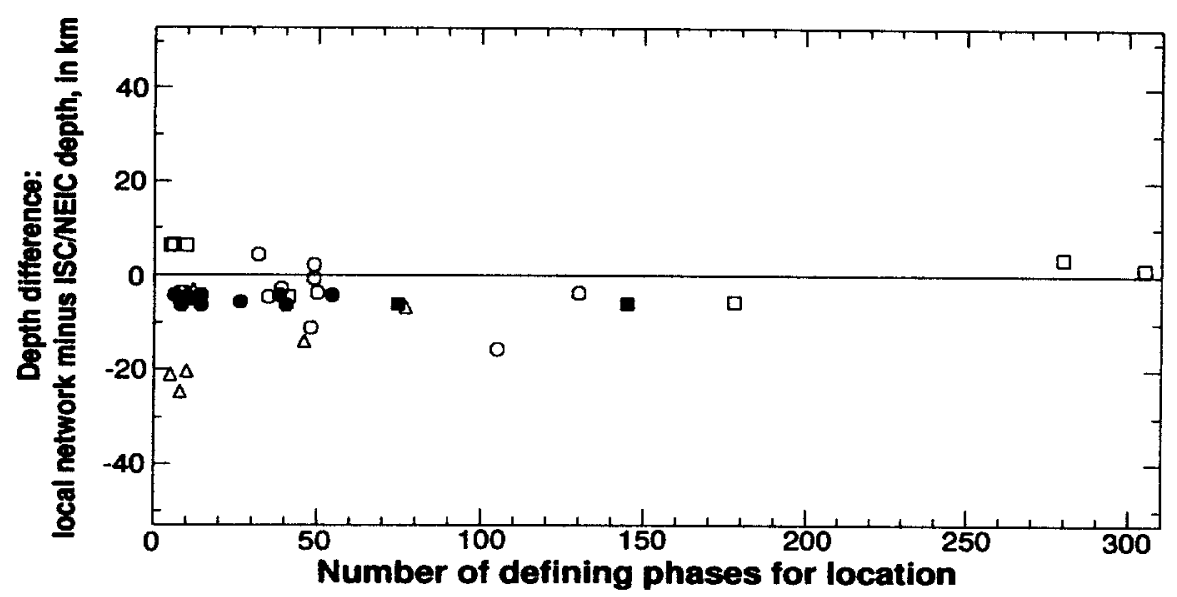

Figure 6. Difference in depth determinations between ISC, NEIC, and the local networks as a function of the number of stations used in determining the event location. Open symbols are ISC determinations. Solid symbols are NEIC determinations. Symbols are as follows: triangles Tabas Iran, squares - El Asnam Algeria, circles - Spitak Armenia. Zagros Iran depths are not included because the local network determination set the depth at $30 \mathrm{~km}$ for all events.

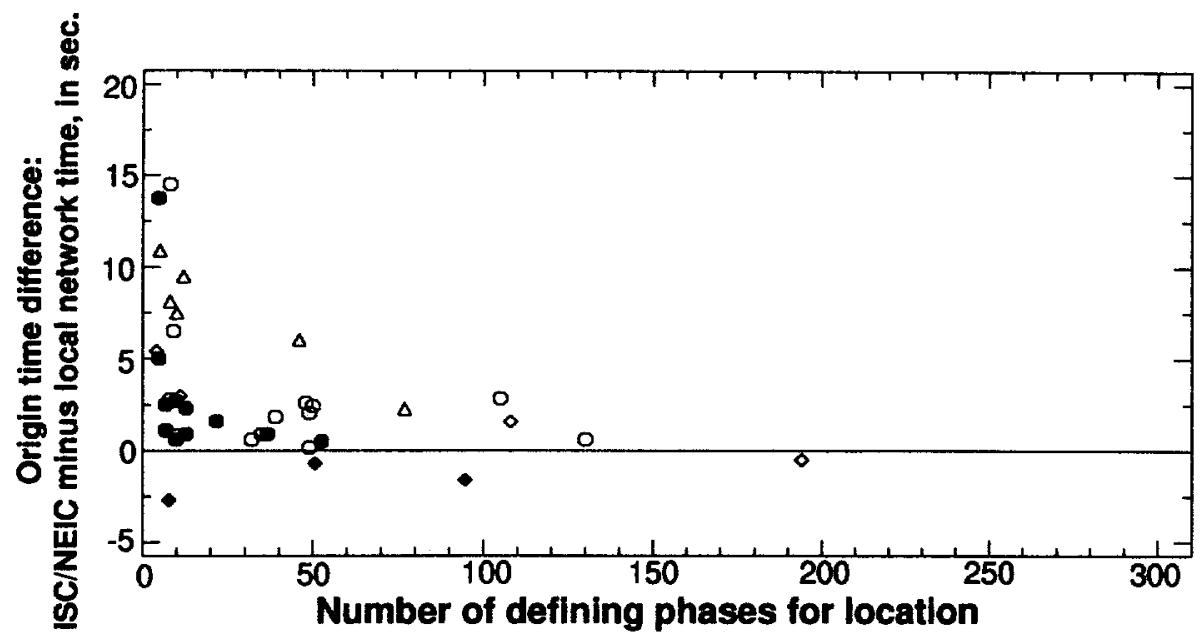

Figure 7. Origin time difference between well-located events and teleseismic determinations versus the number of stations (phases) used for the location determination. Solid symbols are NEIC determinations, open symbols are ISC determinations. Refer to data in Tables 1, 2 and 4. Symbols are as follows: triangles - Tabas Iran, circles - Spitak Armenia, diamonds - Zagros Iran. Accurate origin times were not available from the local network for the Algeria aftershocks. 


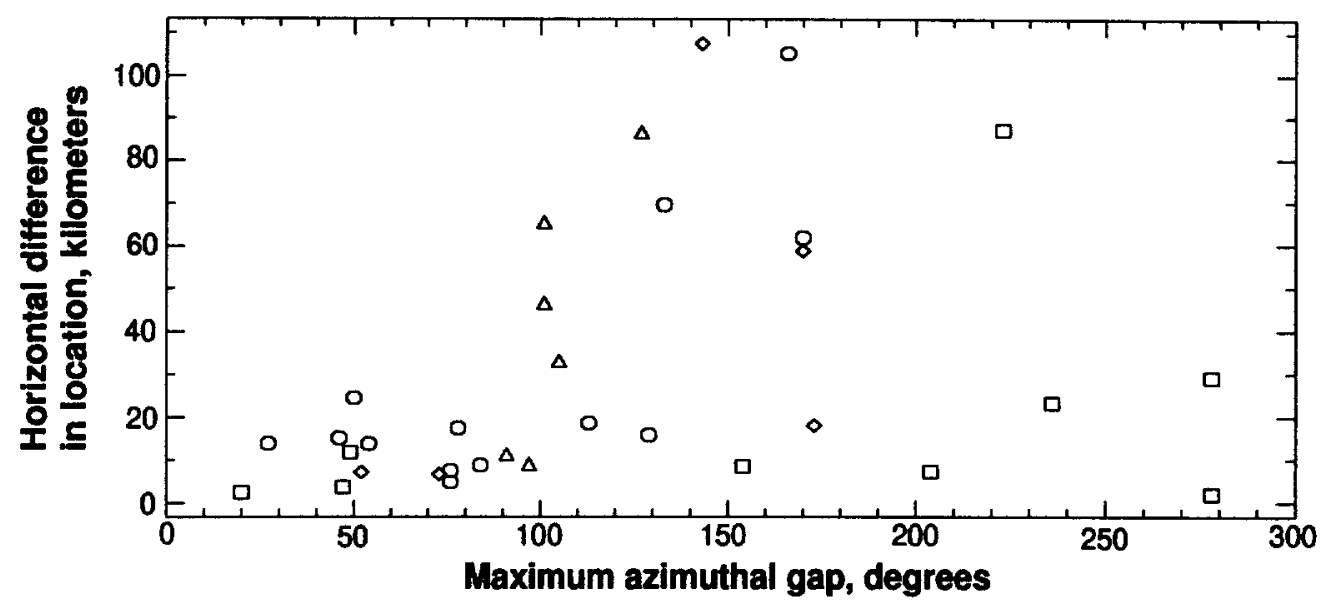

Figure 8. Difference in epicentral location versus maximum azimuthal gap for the ISC-located events of Tables 1-4. Symbols are as follows: triangles - Tabas Iran, squares - El Asnam Algeria, circles - Spitak Armenia, diamonds - Zagros Iran.

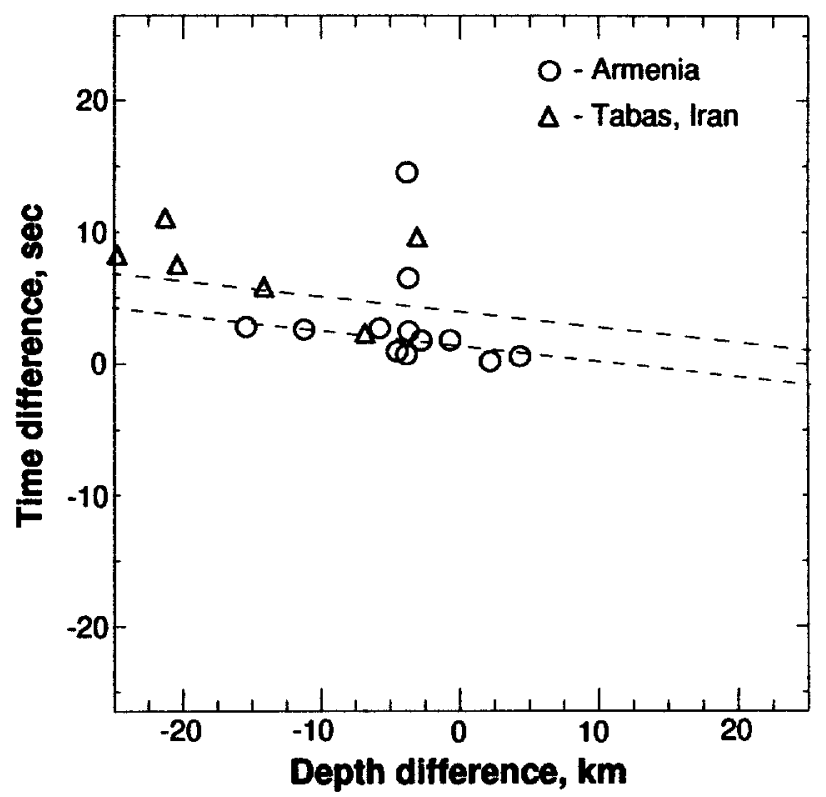

Figure 9. Origin time difference versus depth difference between the well-located events and the teleseisme determinations. Refer to Tables 2 and 4 . Dotted lines have slopes $(-0.33 \mathrm{~s} / \mathrm{km})$ similar to those determined by Billings et al. (1988) for an event in Iran. Symbols are as follows: triangles - Tabas Iran, circles - Spitak Armenia. Accurate origin times were not avallable from the local network for the Algerian aftershocks and depths were fixed at $30 \mathrm{~km}$ for the Zagros Iran local network determinations. 
Based on the above findings, I performed one additional test of the accuracy of teleseismic locations by looking at $P_{n}$ travel times from the ILPA data. Figure 10 compares the reduced travel times for 127 events recorded by ILPA during 1978 and 1979. Distances in Fig. 10 are determined from the ISC locations for each event, and the data is separated into groups with greater than or less than 40 stations used in the location. The cluster of data at a distance of $600-700 \mathrm{~km}$ is mainly from aftershocks of the Tabas-e-Golshan earthquake. Better located events (with $>40$ stations) within $600 \mathrm{~km}$ show much less scatter in reduced travel time than the poorly located events (with $<40$ stations). For distances $>800 \mathrm{~km}$, the reduction in scatter for better locations is not obvious; this may be because travel time differences caused by crustal structure variations play an increasingly greater role as distance increases.

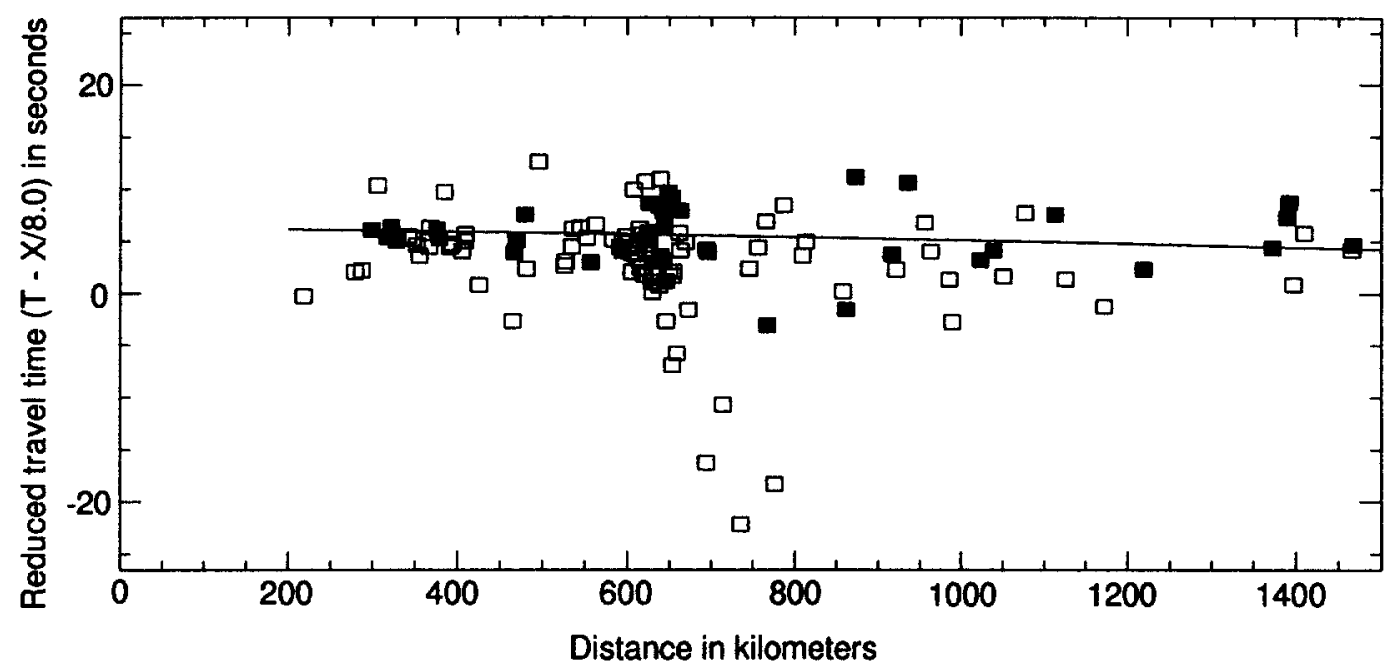

Figure 10. Reduced travel time plot for Pn travel times from the ILPA data set. Solid symbols are events located by the ISC with for $\mathbf{4 0}$ or more stations used. Open symbols are events located by the ISC with less than $\mathbf{4 0}$ stations. The solid line is the reduced travel time for the IASPE91 model with a source depth of $10 \mathrm{~km}$ and $P_{\mathbf{n}}$ velocity $8.1 \mathrm{~km} / \mathrm{s}$.

The importance of this study for regional seismic characterization is that it defines the level of confidence for ISC teleseismic locations in the Middle East and North Africa region. Based on this study, we should rely only on teleseismic locations with 40-50 stations reporting or events with magnitude greater than ISC $\mathrm{M}_{b} 4.4$ - 4.5 (NEIC $\mathrm{M}_{\mathrm{b}} 4.7$ - 4.8) for accurate locations of events. Depth determinations will be suspect, even for large events, in the Zagros region unless a high percentage of the stations also include depth phases. In other areas ISC depth determinations are probably better than in Zagros, but should be approached with caution. The aftershock data used in this study also provide excellent ground truth for use with local and regional studies of travel times, attenuation, etc. where waveform data are available. 


\section{Acknowledgments}

Dr. Manuel Berberian, of Najarian Associates, Inc., provided me with a copy of the data from his $\mathrm{Ph}$. D. thesis. Picks of the ILPA waveform data were done by Flori Ryall of Multimax, Inc. I also thank Terri Hauk, of LLNL, for bringing the paper on Spitak aftershocks to my attention. GMT software (Wessel and Smith, 1995) was used to generate many of the figures. This work was performed under the auspices of the U.S. Department of Energy by Lawrence Livermore National Laboratory under contract No. W-7405-ENG-48.

\section{References}

Adams, R.D., 1992, Effects of heterogeneity on earthquake location at ISC, Physics of the Earth and Planetary Interiors, 75, 1-5.

Asudeh, I., 1983, I.S.C. mislocation of earthquakes in Iran and geometrical residuals, Tectonophysics, $95,61-74$.

Berberian, M., 1979a, Discussion of the paper by A.A. Nowroozi, 1976, "Seismotectonic provinces of Iran", BSSA, 69, 293-297.

Berberian, M., 1979b, Evaluation of the instrumental and relocated epicenters of Iranian earthquakes, Geophysical Journal of the Royal Astronomical Society, 58, 625-630.

Berberian, M., 1981, Continental Deformation in the Iranian Plateau, Doctoral thesis, University of Cambridge, England, U.K.

Berberian, M., 1984, Aftershock tectonics of the 1978 Tabas-E-Golshan (Iran) earthquake sequence: a documented active thin- and thick-skinned tectonic case, Geophysical Journal of the Royal Astronomical Society, 68, 499-530.

Billings, S. D., M. S. Sambridge, and B. L. N. Kennett, 1988, Errors in hypocentral location: picking, model, and magnitude dependence, Bulletin of the Seismological Society of America, 84, 1978-1990.

Dorbath, L., C. Dorbath, L. Rivera, A. Fuenzalida, A. Cisternas, R. Tatevossian, J. Aptekman, and S. Arefiev, 1992, Geometry, segmentation and stress regime of the Spitak (Armenia) earthquake from the analysis of the aftershock sequence, Geophysical Journal International, 108, 309-328.

Jackson, J., 1980, Errors in focal depth determination and the depth of seismicity in Iran and Turkey, Geophysical Journal of the Royal Astronomical Society, 61, 285-301.

Jackson, J., and T. Fitch, 1981, Basement faulting and the focal depths of the larger earthquakes in the Zagros mountains (Iran), Geophysical Journal of the Royal Astronomical Society, 64, 561586.

Kennett, B.L.N., and E.R. Engdahl, 1991, Traveltimes for global earthquake location and phase 
identification, Geophysical Journal International, 105, 429-465.

Niazi, M., I. Asudeh, G. Ballard, J. Jackson, G. King, and D. McKenzie, 1978, The depth of seismicity in the Kermanshah region of the Zagros mountains (Iran), Earth and Planetary Science Letters, 40, 270-274.

Wessel, P., and W. H. F. Smith, 1995, New version of the Generic Mapping Tools released. EOS Transactions American Geophysical Union, 76, 329.

Yielding, G., M. Ouyed, G.C.P. King, and D. Hatzfeld, 1989, Active tectonics of the Algerian Atlas mountains-evidence from aftershocks of the $1980 \mathrm{El}$ Asnam earthquake, Geophysical Journal International, 99, 761-788. 


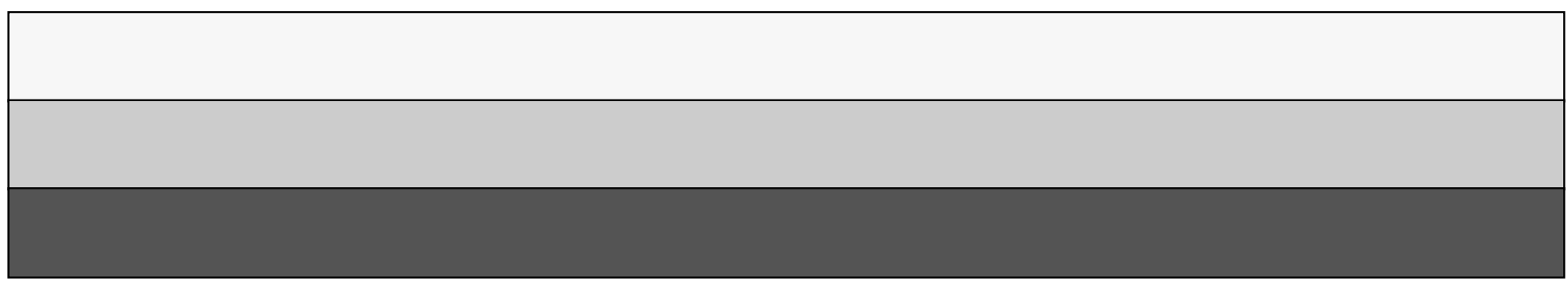

